\title{
Lesotho's 2015 Legislative Election: Providing or Undermining Stability?
}

\author{
Vasabjit Banerjee \\ Mississippi State University, USA and University of Pretoria, South Africa \\ Timothy S Rich \\ Western Kentucky University, USA
}

\begin{abstract}
:
Political unrest in 2014 threatened Lesotho's newly found democratic stability. Observers focus on educating the public about the electoral system and encouraging pre-election coalition discussions. However, this analysis suggests this ignores the institutional influences of Lesotho's electoral system that undermine both public understanding and stability. Furthermore, a statistical analysis of district competition finds the 2015 elections to be largely consistent with previous elections, but that the percentage of rejected ballots correlates with a district victory for the largest party. Although this may simply be a statistical anomaly, the findings highlight structural challenges and reconsideration of electoral reforms.
\end{abstract}

\section{Introduction}

Lesotho gradually transitioned from authoritarian rule to democracy in the 1990s (see Matlosa 2006), after a history of dominant parties, coups and limited role for opposition voices (e.g. McCartney 1973; Gumbi 1995; Olaleye 2004; Cho and Bratton 2006). Despite challenges in establishing democratic roots post-independence (Makoa 2004), even in the absence of religious tension or ethnic divisions (e.g. Maundeni 2010), Lesotho saw relatively peaceful elections following reforms for a new electoral system in 2002. Lesotho currently employs a mixed member system which allocates seats to both single member districts (SMDs) as well as through proportional representation (PR) within the same legislative chamber. This reform to a mixed system in part intended to produce a more representative National Assembly (Elklit 2002), by ensuring significant representation to the opposition. The shift marked the country's first free and 
fair election in 2002, despite protests by the opposition (Makoa 2004), and the Independent Electoral Commission's (IEC) providing marginal means for domestic groups or international observers to challenge election results (Makoa 2004). Nevertheless, institutional reforms appeared to signal the beginning of democratic consolidation, reflected in the elections of 2007 and 2012 (Rich et al 2014), the latter seen as the best political climate since democratization efforts in the early 1990s (Letsie 2013).

However, political instability in 2014, which culminated in an attempted coup d'état and intervention by external third-party mediators, led to an early election for February 2015 that may have undermined popular faith in whether the electoral system could yield stable governing coalitions. Furthermore, whether this electoral system could promote long-term stability in the country in no small part rests on popular perception of the electoral system as fair. In this vein, the Commonwealth Special Envoy's report on Lesotho — completed just prior to the crisis-calls for two additional measures to deepen democracy: first, making citizens' aware of the workings of the electoral system, specifically how votes affect electoral outcomes and the subsequent process of government formation; and, second, parties considering pre-election coalitions and explaining this to voters (Prasad, 2014). However, the recommendations neither suggested changes to Lesotho's lack of formal thresholds for the PR seats, nor the legal requirement under Section 82(1)(b) of the constitution, which requires the National Assembly to form a government within 14 days of the general election.

Although a vast literature on mixed legislative systems has emerged since 1990, few of these works address their impact in countries with limited democratic roots, especially those which were not formerly communist. In addition, Lesotho is rarely included in cross-national analyses of mixed systems, although a cursory evaluation suggests that Lesotho's electoral 
institutional context does not make it an outlier among the broader population of cases. ${ }^{1}$

Furthermore, little work on mixed systems attempts to tie this literature to the growing research on electoral fraud. Considering the added complexity of mixed systems and the general public ignorance of how votes translate into seats in this context, this provides the potential for at least the perception of fraud. The research presented here suggests that the Commonwealth Special Envoy, while well intentioned, may be overlooking areas in which Lesotho's electoral institutions and electoral administration undermines citizens' confidence in the electoral process' fairness and ability to deliver political stability.

The format of this analysis is as follows. First, a brief summary of mixed member systems and Lesotho's institutional framework is presented. This is followed by a summary of the 2014 political crisis and subsequent election. After a brief comparison of 2015 district competition to previous elections, empirical analysis of district victories for the Democratic Congress uncovers a correlation between victory and the percent of rejected ballots. While not a smoking gun, and additional evidence suggests the actual substantive effect is negligible, such a correlation may be cause for concern within the unstable Lesotho context. In conclusion, additional suggestions regarding means to encourage democratic stability in Lesotho are presented.

\section{Mixed Member Systems and Lesotho}

The literature on mixed systems builds upon Duverger's Law (Duverger 1954) and its expectation of two-party competition in single member districts (SMDs) and multiparty competition under proportional representation (PR). Proponents of mixed member systems expected the two seat types to operate as if independent from one another (e.g. Lancaster and Patterson 1990; Moser and Scheiner 2004), with constituency focus in two-party dominated 
district races and national policy in multiparty races for PR seats. Others argued that the simple existence of two electoral rules within the same chamber created a form of contamination and thus Duverger's Law should not hold (e.g. Herron and Nishikawa 2001; Cox and Schoppa 2002; Ferrara et al. 2005).

Lesotho enacted a mixed system in no small part due to the one-party dominance under a single member district system (e.g. Matlosa 1999; Molomo 1999). Lesotho’s type of mixed system is more consistent with the contamination thesis. First, as a mixed member proportional (MMP), the electoral system requires the overall distribution of seats to be proportional. Such systems, also including Germany and New Zealand, contrast with mixed member majoritarian (MMM), where the results of district competition do not influence the distribution of PR seats. ${ }^{2}$ Secondly, Lesotho uses a single ballot rather than the more common two-ballot system. Here, much like Mexico, voters choose a district candidate and these district votes are then aggregated to allocate PR seats. Voters do not directly vote for PR seats and thus cannot split their votes between SMD and PR tiers. Thus supporters of smaller parties must vote for non-viable district candidates to potentially win PR seats. Similarly parties must run non-viable district candidates to be eligible for PR seats. Furthermore, the literature on MMP systems, one which potentially informed the decision to enact such as system in Lesotho, rests largely on evidence from Germany and New Zealand, two stable democracies. Meanwhile, little literature directly tackles the role of a single ballot mixed system, with few countries (notably Albania and South Korea) having experience under both one and two-ballot forms. Thus, while the complexities of twovote MMP systems are believed to discourage strategic voting (e.g. Reynolds et al., 2005), the one-vote system potentially exacerbates the practice. 


\section{The 2014 Political Crisis and 2015 Election}

The general election of February 2015 has its origins in the political crisis that occurred during the second-half of 2014. The crisis centered on the leaders of the two major political parties of the ruling coalition, Prime Minister Thomas Thabane of the All Basotho Convention $(\mathrm{ABC})$ and Deputy Prime Minister Mothetjoa Metsing of the Lesotho Congress for Democracy (LCD). Although the third coalition partner, the Basotho National Party (BNP) led by Sports Minister Thesele Maseribane, did not actively participate in the confrontation, it reportedly sided with the LCD in 2014 before moving against in 2015 (Letuka 2015). Thabane and Metsing had come to power in June 2012, after electorally defeating the Lesotho Convention for Democracy Ntsu Mokhele (LCD-NM) led by then Prime Minister Bethuel Pakalitha Mosisili.

In the context of this paper's analysis of electoral institutions, it is important to note that until 2012 all three leaders had belonged to the LCD. Thabane created the ABC after Mosisili refused to give up leadership of the party; Mosisili formed the LCD-NM; and, Metsing led the remaining LCD membership. Thus, the electoral calculations of the three leaders, which led to the LCD's fragmentation, occurred under the same rules that governed the 2015 elections. Extant research posits that these rules: increase party fragmentation; makes coalition formation contingent on office and rent seeking individual leaders rather than parties' ideological or policy preferences (Kapa 2008); as well as, engenders coalition governments that hinder effective governance (Clottey 2014).

Perhaps ironically, the MMP electoral system was chosen due to the claims that the old single member district (SMD) system stifled competition. Even after the authoritarian rule which effectively disenfranchised smaller parties ended (see Cho and Bratton 2006), lopsided 
parliamentary representation continued. For example, in the 1998 election, the LCD won 79 of 80 seats.

The 2014 crisis began with Thabane's anticorruption drives, which members of the opposition considered as a method of persecuting his political rivals. The first targets centered on members of the Mosisili administration, including Timothy Thahane the former Finance Minister accused of defrauding a farm, Monyane Moleleki the former natural resources minister accused to rigging contracts for diamonds (Jordan 2014a). In June 2014, Metsing threatened to withdraw his party's support from the ruling coalition, and called for a vote of no confidence (Wanjiru 2015). To stop this challenge, Thabane suspended parliament. At this juncture, Metsing was also accused of misallocation of funds for the acquisition of equipment, which he declared as politically motivated (Tefo 2014a). He subsequently challenged the acquisition of information on his bank accounts as unconstitutional at the Constitutional Court (Tefo 2014b).

Additionally, according to diplomats, the Lesotho Defense Forces (LDF) and the Lesotho Mounted Police (LMP) allegedly split on party lines: the LDF supporting Metsing and the LMP backing Thabane (“Lesotho Army Denies Prime Minister's Coup Accusation” 2014). Consequently, after Thabane sought to replace the commander of the LDF Lieutenant-General Tlali Kamoli with Lieutenant General Maaparankoe Mahao, the LDF occupied the police headquarters, disarmed the police ("Lesotho Military Seizes Police Headquarters in Possible Coup Attempt" 2014), and killed a police office in the process (News24, 2015). General Kamoli subsequently accused Prime Minister Thabane of using the LMP to attack opponents (Mohloboli 2014). The Police stated that LDF personnel were looking for incriminating files related to corruption and "politically motivated bomb attacks" against General Kamoli and other LDF 
personnel during their occupation of various police stations ("Renegade Lesotho General 'Seizes Weapons" 2014).

Faced with the disarming of the police and the jamming of communications media, which indicated a coup, Thabane fled to South Africa and implicitly accused Metsing of collaborating with General Kamoli (“Zuma to Meet Thabane in South Africa as Lesotho Calms” 2014). Subsequently, Minister of Public Service Motloheloa Phooko took over as interim Prime Minister. Mediation by South Africa's Deputy President Cyril Ramaphosa, supported by the Southern African Development Community (SADC) countries, led to Thabane's return to Lesotho under a SADC protection force. In turn, after the South African intervention, Generals Kamoli and Mahao and the Police Commissioner Khothatso Ts'oona were temporarily exiled to Uganda, South Sudan, and Algeria respectively, to learn how a military functions in a democracy; Mahao and Ts'oona being given positions within the bureaucracy of the African Union (Dikarabo 2014).

In order to settle the political impasse, parliament was dissolved in December 2014 (Office of the Government Secretary, Lesotho 2014). It is pertinent to mention, Parliament dissolved itself after passing the budget, but the vote of no confidence was not undertaken (Jordan 2014b) based on the agreement between political parties', which was brokered by Cyril Ramaphosa and enshrined in the Maseru Facilitation Declaration (South Africa, 2014). Subsequently, a general election was held on 28 February 2015 under the aegis of the SADC force, while the Lesotho Army and Police were confined to their barracks (Wanjiru 2015).

The major political parties in this election were the ABC led by Thabane, the LCD headed by Metsing, Democratic Congress (DC) headed by Mosilsili, and the BNP led by 
Maseribane. It was reported that the DC and LCD had formed a pre-electoral alliance (BBC News 2015).

Despite incidents of pre-electoral violence between members of the LDF and the Police Force ("2 Soliders Shot Ahead of Lesotho Elections" 2015), The SADC electoral observers declared the elections to have been "peaceful, transparent, credible, free and fair" (NkoanaMashanabe 2015). The United Nations and the United States government also declared the elections to be free and fair, commending the Independent Electoral Commission's of Lesotho's efforts (Ban 2015).

The three largest parties were: the $\mathrm{DC}$ with 47 seats, the $\mathrm{ABC}$ with 46 seats, and, the LCD with 12 seats. The DC and LCD dominated coalition, led by Mosilsili as Prime Minister and Metsing as the Deputy Prime Minister, took over as the new government. In early April of 2015, General Kamoli returned from exile to resume his duties as the Army Commander, but General Maaparankoe Mahao-in contravention of his appointment as Army Commander by exPrime Minister Thabane — was to remain a Brigadier (Ngatane 2015).

In conclusion, the electoral turnout was low, approximately 47 percent, while the margin of victory in popular votes was thin: the $\mathrm{DC}$ having acquired 3,551 votes more than the $\mathrm{ABC}$, or less than one percent of the over half million votes cast. However, Dimpho Motsamai, an expert based at the Institute for Security Studies at Pretoria, posits that political leaders not the MMP electoral institutions were responsible for the democratic election: in fact, the electoral institutions prevented the one-party dominance that repeatedly caused political violence under the old system (Allison 2015). While one-party dominance was again avoided by the MMP system, the electoral format did little to manufacture a stable majority. Nor does the electoral 
format encourage public understanding of how the two electoral seats interact, a common concern among mixed systems.

\section{Empirical Analysis}

How do the 2015 elections compare to both theoretical expectations on mixed systems and maintaining democratic goals, particularly democratic stability, in Lesotho? Table 1 breaks down the distribution of seats by the two electoral tiers. The results clearly show the continued strength of 2012's largest parties, the Democratic Congress (DC) and the All Basotho Convention $(\mathrm{ABC})$. Meanwhile the total number of parties winning at least one seat was the same as 2002 (10) down from a peak of 12 in 2012. The effective number of parties, a weighted measurement of size of electoral or legislative parties, further declined in 2015, from 3.67 n 2012 down to 3.18, in large part to the success of the DC and ABC. Furthermore, while turnout was low $(46.61 \%)$, no party boycotted the election.

The necessity for a coalition government following the 2015 election, when parties had ill prepared for such an outcome, is common outcome among MMP systems and thus should not have been a surprise. After all, this was also the outcome in 2007, when the DC won a plurality of seats (48 out of 120), yet ultimate became the main opposition to an ABC-led ruling coalition. In contrast, in 2015, the DC ultimately coordinated with the Lesotho Congress for Democracy and five other parties to cobble together a majority. While this may meet the short-term needs of a minimal winning coalition, it also allows for smaller parties to essentially blackmail larger parties for greater concessions or risk a change in power. Thus, while promoting multiparty competition in one aspect intended to create stability, in terms of governability, this may be a hindrance. 
Since Lesotho uses a one-vote system and districts outnumber PR seats, an examination of district competition is warranted. The average vote concentration among the top two district candidates of $77.66 \%$ of the vote is consistent with the contamination thesis. This was not dissimilar from the last three elections $(2002,2007,2012)$ where the concentration ranged from 72.31 to 81.80 percent. Similarly winners averaged just slightly less than half the vote (49.76\%), indicative of the party fragmentation at the district level, where the average number of candidates reached fourteen and peaked at eighteen. This differs little from 2012 where the average number of district candidates was 13 . Admittedly most of these were nonviable entries, but does suggest greater party fractionalization than district competition in institutionalized Western democracies.

The 2015 district elections also mirror those of 2012, where district winners averaged 46.8\% of the vote, compared to over 57\% in both 2002 and 2007. Most districts also remain marginally competitive, with an average winner's margin of $21.86 \%$ in 2015 , consistent with 2012's election (21.28\%), and an improvement from 2002 and 2007 (36.1\% and 33.25\% respectively). Admittedly district competition in new and established democracies alike is often noncompetitive in no small part due to constituency services and incumbency advantages. Nevertheless, the relative parity of district victories by the $\mathrm{DC}$ and $\mathrm{ABC}$ suggest the continuance of two-party dominant competition rather than a return of single party domination.

Table 1: Breakdown of Seats in 2015 Election

\begin{tabular}{|ccc|}
\hline & District & PR \\
Democratic Congress (DC) & 37 & 10 \\
All Basotho Convention (ABC) & 40 & 6 \\
Lesotho Congress for Democracy (LCD) & 2 & 10 \\
Basotho National Party (BNP) & 1 & 6 \\
Other Parties & 0 & 8 \\
\hline
\end{tabular}


The 2015 election does seem to differ from previous elections in terms of how the number of district candidates influenced vote concentration. Table 2 presents an OLS regression on the vote concentration among the top two candidates with the number of district candidates as the sole independent variable. Using the data from Rich et al. (2014) and supplemented with 2015 we see that the raw number of district candidates negatively correlates with vote concentration across all three models; however, only in 2015 does it fail to reach statistical significance at all. In other words, it appears that the influence of the also-rans has declined markedly since even 2012. This may be a sign that voters are identifying which party's candidates are viable at the district or possibly even in the aggregate party list level, factors which in the long term should reduce the space between electoral expectations and results.

Table 2:

The Number of District Candidates and Vote Concentration (2002, 2012, and 2015)

\begin{tabular}{|lllllll|}
\hline & 2002 & & 2012 & & 2015 & \\
& Coeff. & SE & Coeff. & SE & Coeff. & SE \\
Number of Candidates & $-0.14^{* * * *}$ & 0.27 & $-2.26^{* * * *}$ & 0.27 & -0.39 & 0.51 \\
& & & & & & \\
Constant & 92.08 & 2.95 & 101.68 & 3.58 & 83.13 & 7.16 \\
$\mathrm{~N}$ & 78 & & 80 & & 80 & \\
Adjusted $\mathrm{R}^{2}$ & 0.17 & & 0.47 & & 0.01 \\
\hline
\end{tabular}

While preliminary district results are largely consistent with previous elections, this gives us marginal insight into whether the elections were fair. Observers from the Southern Africa Development Community (SADC) declared the elections free and fair, reiterated by UN Secretary-General Ban Ki-Moon (SADC 2015; United Nations 2015), but this does not mean that fraud may be missed by the naked eye. One means to address potential fraud is through the reported digits in subnational results (e.g. Mebane and Sekhon 2004; Mebane 2006; Beber and Scacco 2002), identifying whether, for example, the rates of ending digits (0-9) in results beyond 
one or two standard deviations would suggest the possible of electoral fraud. Put another way, fabricated results tend to over-represent certain ending digits (e.g. $0 \mathrm{~s}$ and $5 \mathrm{~s}$ ), although any number outside of two standard deviations from the mean would be cause for alarm. Rich et al. (2014) use a similar method and find no systematic evidence of fraud in Lesotho's 2012 election. We replicate these findings for 2015 with separate tests of the reported number of registered voters, total voters, and the number of votes rejected (Table 3). However, none of the digits were beyond one standard deviation below or above the mean, with only one section (the reported number of district registered voters ending in a six) coming close to two standard deviations, thus providing no clear evidence of fraud. Thus, much like 2012, the evidence suggests that vote tallies were not manipulated after the fact.

Table 3: Distribution of Last Digit in District Elections ( $\mathrm{SD}=$ standard deviation)

\begin{tabular}{|cccc|}
\hline Ending Digit & Registered & Total & Rejected \\
0 & 2 & 2 & 12 \\
1 & 6 & 12 & 9 \\
2 & 5 & 4 & 9 \\
3 & 11 & 12 & 3 \\
4 & 9 & 6 & 10 \\
5 & 6 & 4 & 9 \\
6 & 15 & 11 & 10 \\
7 & 7 & 9 & 6 \\
8 & 8 & 12 & 7 \\
9 & 11 & 8 & 5 \\
& & & \\
mean & 8 & 8 & 8 \\
SD & 3.68 & 3.80 & 2.71 \\
& & & \\
1SD below & 4.32 & 4.20 & 5.29 \\
1SD above & 11.68 & 11.80 & 10.71 \\
& & & \\
2SD below & 0.64 & 0.40 & 2.58 \\
2SD above & 15.36 & 15.60 & 13.42 \\
\hline
\end{tabular}


As a second measure, we analyzed rates of the total ballots that were rejected, which ranges from 0.32 percent to 3.77 percent of all votes and with a mean 1.37 percent. While many reasons may emerge as to why ballots were rejected, a systematic pattern in favor of a party would at the very least justify a closer investigation of the election results. Table 4 presents three logit models with the dependent variable whether or not the district elected a DC candidate. Model 1 includes only one independent variable: the percentage of total ballots that were rejected. Here the results are clear: the percentage of rejected ballots strongly correlate with a DC district victory. Not only is the pseudo $\mathrm{R}^{2}$ non-negligible (.25), this model with a sole independent variable correctly classified $70 \%$ of cases. Without additional information, such findings should certainly be cause for concern.

Admittedly the percentage of rejected ballots may be obscuring the influence of other factors. For example, it may simply be that the DC did better in close races, where rejected ballots may have a greater influence. Similarly, the total number of votes in the district as well as voter turnout may explain these patterns. Many rejected ballots could be caused by confusion over which parties are running candidates locally; and, a simple bivariate OLS regression confirms a negative correlation between the number of candidates and the percent of rejected ballots, significant at $.01\left(\mathrm{R}^{2}=.08\right)$. Finally, there may be simply greater confusion about the electoral process in rural areas versus the urban areas.

Model 2 thus includes a measure of the winner's margin in percent (logged), to identify competitive versus non-competitive districts. This is supplemented with controls for the total district votes (logged), district turnout (in percentages), the raw number of district candidates, and a dummy variable for districts in the capital state of Maseru, using this as a proxy for an urban-rural divide. The results are consistent with Model 1, with the percentage of rejected 
ballots strongly correlating with a DC district win. Furthermore, the number of candidates negatively correlated with a DC victory, while Maseru positively correlated with DC success. These additions considerably improve the pseudo $\mathrm{R}^{2}$ and raise the percentage of cases correctly classified by the model to $81.25 \%$.

Model 3 includes an additional dummy variable for whether or not the DC won the district in the previous election. While not a perfect proxy for incumbency, this does attempt to capture why DC candidates fared better in certain districts. The results here are largely consistent with the first two models. As expected a previous DC win in the district strongly correlated with a win in 2015. However, the percentage of rejected ballots still correlated with a DC win, albeit only at the .10 level.

Table 4: Logit Regressions on the Election of a DC District Candidate

\begin{tabular}{|c|c|c|c|c|c|c|}
\hline & \multicolumn{2}{|l|}{ Model 1} & \multicolumn{2}{|l|}{ Model 2} & \multicolumn{2}{|l|}{ Model 3} \\
\hline & Coeff. & SE & Coeff. & SE & Coeff. & SE \\
\hline Rejected Ballots (\%) & $2.40 * * * *$ & 0.61 & $2.82 * * * *$ & 0.86 & $1.84 *$ & 1.05 \\
\hline Winner's Margin (logged) & & & $0.57 *$ & 0.33 & 0.58 & 0.52 \\
\hline Total Votes (logged) & & & -3.77 & 2.82 & -0.32 & 3.33 \\
\hline Voter Turnout (\%) & & & -0.06 & 0.11 & -0.15 & 0.12 \\
\hline Number of Candidates & & & -0.23 & 0.16 & -0.05 & 0.24 \\
\hline Maseru & & & 1.36 & 0.99 & 1.21 & 1.34 \\
\hline DC Win in 2012 & & & & & $3.96 * * *$ & 1.01 \\
\hline Constant & $-3.47 * * * *$ & 0.86 & 33.98 & 22.26 & 3.82 & 7.57 \\
\hline $\mathrm{N}$ & 80 & & 80 & & 80 & \\
\hline Pseudo $\mathrm{R}^{2}$ & 0.25 & & 0.38 & & 0.60 & \\
\hline \% Correctly Classified & $70.00 \%$ & & $81.25 \%$ & & $87.50 \%$ & \\
\hline
\end{tabular}

Since logit models are non-linear, predicted probabilities provide additional insight. Using Model 1, the predicted probability of a DC district victory ranges from $6.3 \%$ at the rejected minimum of 0.32 percent of ballots up to $99.63 \%$ at the reject maximum at 3.77 percent. Predicted probabilities from Model 2 (holding all other variables at their mean) produce similar 
results. A district victory by the DC is predicted at only $4.66 \%$ where rejected votes as a share of total votes are at their minimum, compared to $99.63 \%$ at their max. Finally, Model 3 sees a similar effect: $9.37 \%$ at the minimum and $95.67 \%$ at the maximum.

While these results may suggest an effort to reject ballots for partisan purposes, a closer analysis finds no smoking gun. In particular, the percentage of rejected ballots only exceeded the margin of victory in one district race by a little more than one percent: Constituency 10 in Leribe. Nor did this district elect a DC candidate, but rather an ABC candidate. Thus, if the rejection of ballots were intended to sway elections in favor of the DC, the results here suggest that the efforts were ineffective and unnecessary.

\section{What This Means for Lesotho}

The results of the 2015 election may provide relief in terms of maintaining competitive elections, but the findings here suggest considerable room for reform. First, public education efforts to boost understanding of the electoral system are certainly a welcome addition. However, this ignores what to a certain extent are predictable concerns under a one-vote MMP system. The system neither encourages easy comprehension of how votes translate into seats nor does it encourage stable ruling coalitions. In the quest to avoid the dummy lists of a two vote MMP system, Lesotho simply discarded the second ballot, rather than consider means in which a twovote system may have been advantageous, either as an MMM system or with rigid requirements that parties slate candidates in both tiers.

Secondly, while greater attention to publicizing pre-election coalitions will likely encourage a greater link between voter expectations and outcomes, such efforts will be undermined if the perceptions of the electoral process remained tarnished. The empirical analysis here suggests a consistent correlation between rejected ballots and a DC victory Although this 
pattern may simply be a statistical artifact rather than intentional electoral manipulation, the presence of such patterns may be cause for alarm among electoral losers. After all, the stability of democratic systems relies on parties not only losing elections (Przeworski 1991), but electoral losers consenting to those losses (e.g. Anderson et al. 2005). Thus, greater effort to uncover the reasons behind rejected ballots and education efforts to limit wasted ballots should assist in building confidence in the electoral institutions.

However, the political parties' mutual distrust — evidenced during the crisis of 2014could impede their leaders from undertaking the institutional changes suggested here; because the fragile post-electoral equilibrium perhaps exists partially due to the parties' acceptance of extant electoral rules. Consequently, third-parties, whether specific countries or regional and international organizations, need to act as mediators between these political leaders to consensually make the suggested changes in the electoral rules. Mediators can alleviate distrust by increasing communication between political leaders and set the agenda centered on the changes suggested by this paper (Beardsley et al. 2006). Such methods would reduce the need for expensive military interventions to suppress conflicts and, more importantly, the unwarranted loss of life and assets that necessitates them.

\footnotetext{
${ }^{1}$ Using the data from Rich (2015) that covers most district elections in mixed systems from 1990-2012, we reran his original models which control for institutional variations within mixed systems and added a dummy variable for Lesotho. This addition never reached statistical significance, suggesting that the country's district level results are not outliers among the family of mixed systems.

${ }^{2}$ Under MMM, the total results may be very disproportional if one party wins more district seats than their PR vote share. Under MMP, party list seats are allocated only after adjusting for district victories.
} 


\section{References}

2 Soldiers Shot Ahead of Lesotho Elections (2015) City Press, 2 February.

Available at: http://www.citypress.co.za/news/2-soldiers-shot-ahead-lesotho-elections/.

Allison S (2015) Think Again: Democracy Reigns in Lesotho-But Which Democracy Exactly? Institute for Security Studies-Today, 23 March. Available at: http://www.issafrica.org/isstoday/think-again-democracy-reigns-in-lesotho-but-which-democracy-exactly.

Anderson CJ, Blais A, Bowler S, Donovan T and Listhaug O (2005) Losers' Consent: Elections and Democratic Legitimacy. Oxford: Oxford University Press.

BBC News (2015) Will Lesotho Election be Peaceful? 27 February.

Available at: http://www.bbc.com/news/world-africa-31643701.

Beardsley KC, Quinn DM, Biswas B and Wilkenfield J. (2006) Mediation Style and Crisis Outcomes. Journal of Conflict Resolution 50(1): 58-86.

Beber, B and Scacco A (2012) What the Numbers Say: A Digit-Based Test for Election Fraud. Political Analysis 20(2): 211-234.

Cho W and Bratton M (2006) Electoral Institutions, Partisan Status, and Political Support in Lesotho. Electoral Studies 25(4): 731-750.

Clottey P (2014) Lesotho PM Thabane to Seek Re-Election Next Year. Voice of America. 4 October. Available at: http://www.voanews.com/content/lesotho-pm-thabane-to-seek-re-electionnext-year/2472666.html.

Cox KE and Schoppa LJ (2002) Interaction Effects in Mixed-Member Electoral Systems. Comparative Political Studies 35(9): 1027-1053.

Elklit J (2002) Lesotho 2002: Africa's first MMP elections. Journal of African Elections 1(2): 110.

Ferrara F, Herron ES and Nishikawa M (2005) Mixed Electoral Systems: Combination and its Consequences. New York: Palgrave.

Gumbi L (1995) Instability in Lesotho: A Search for Alternatives. African Security Review4: 3746.

Herron ES and Nishikawa M (2001) Contamination Effects and the Number of Parties in Mixed Superposition Electoral Systems. Electoral Studies 20(1): 63-86.

Jordan MA (2014a) Lesotho Wrestles with Corruption. Mail and Guardian,12 December. Available at: http://mg.co.za/article/2014-12-11-lesotho-wrestles-with-corruption.

Jordan MA (2014b) Lesotho Parliament to Reconvene in Bid to End Crisis. Business Day, 17 October. Available at: http://www.bdlive.co.za/africa/africannews/2014/10/17/lesothoparliament-to-reconvene-in-bid-to-end-crisis. 
Jordan MA (2015) Climate of Uncertainty and Fear Haunts Upcoming Lesotho Poll. Mail and Guardian, 13 February. Available at: http://mg.co.za/article/2015-02-13-00-climate-ofuncertainty-andfear-haunts-upcoming-lesotho-poll.

Kapa, MA (2008) The Politics of Coalition Formation and Democracy in Lesotho. Politikon 35(3): 339-356.

Lancaster, TD and Patterson WD (1990) Comparative Pork Barrel Politics: Perceptions from the West German Bundestag. Comparative Political Studies 22(4): 458-477.

Lesotho Army Denies Prime Minister's Coup Accusation (2014). Deutsche Welle, 30 August. Available at: http://www.dw.de/lesotho-army-denies-prime-ministers-coup-accusation/a17890353.

Lesotho Military Seizes Police Headquarters in Possible Coup Attempt (2014). Deutsche Welle, 30 August. Available at: http://www.dw.de/lesotho-military-seizes-police-headquarters-inpossible-coup-attempt/a-17889943.

Letsie T (2013) The 2012 General Elections in Lesotho: A Step Towards the Consolidation of Democracy. Journal of African Elections 12(1): 65-83.

Letuka C.(2015) BNP Takes on Metsing. Lesotho Times, 29 January. Available at: http://lestimes.com/bnp-takes-on-metsing/.

Makoa FK (2004) Electoral Reform and Political Stability in Lesotho. African Journal on Conflict Resolution 4(2): 79-95.

Matlosa K (1999). Conflict and Conflict Management: Lesotho's Political Crisis After the 1998 Election. Lesotho Social Science Review 5(1): 163-196.

Matlosa K (2006) Electoral System Design and Conflict Mitigation: The Case of Lesotho. In: Democracy, Conflict and Human Security: Pursuing Peace in the 21 st Century: Further Readings, pp. 94-110. Available at: http://www.idea.int/publications/dchs/upload/dchs_vol2_sec3_3.pdf

Maundeni Z (2010) Political Culture as a Source of Political Instability: The Case of Lesotho.African Journal of Political Science and International Relations 4(4): 128-139.

McCartney WJA (1973) The Lesotho General Election of 1970. Government and Opposition 8(4): 473-494.

Mebane WR (2006) Election Forensics: Vote Counts and Benford's Law (working paper). Available at: http://em.fis.unam.mx/ mochan/elecciones/paperMebane.pdf

Mebane WR and JS Sekhon (2004) Robust Estimation and Outlier Detection for Overdispersed Multinomial Models of Count Data. American Journal of Political Science 48(2): 392-411. 
Mohloboli K (2014) I am Still LDF Commander - Kamoli. Lesotho Times, 30 August. Available at: http://lestimes.com/still-ldf-commander-kamoli/.

Molomo M (1999). External Military Intervention in Lesotho's Recent Political Crisis. Lesotho Social Science Review 5(1): 133-162.

Moser RG and Scheiner E (2004) Mixed Electoral Systems and Electoral System Effects: Controlled Comparison and Cross-National Analysis. Electoral Studies 23(4): 575-599.

Army Confined to Barracks as Lesotho Votes (2015). News24, 27 February. Available at: http://www.news24.com/Africa/News/Army-confined-to-barracks-as-Lesotho-votes20150227.

Ngatane N (2015) Lesotho's Kamoli to Take Over as Army Commander. SABC News, 6 April. Available at:

http://www.sabc.co.za/news/a/0ddee90047ea01e085c6f74405f77b26/LesothosundefinedKam oliundefinedtoundefinedtakeundefinedoverundefinedasundefinedArmyundefinedCommander20150604>.

SADC Electoral Observation Mission (SEOM) To the Kingdom of Lesotho, Nkoana-Mashanabe, M (2015). Statement, 2 March. Available at: http://www.sadc.int/files/4814/2536/7810/SEOM_STATEMENT_LESOTHO_final__02.03.2015.pdf.

Office of the Government Secretary, Lesotho (2014) Press Release. 4 December. Available at: http://www.sadc.int/files/2614/1810/9360/Press_release_on_the_Dissolution_of_the_Parliam ent_En.pdf

Olaleye W (2003) Democratic Consolidation and Political Parties in Lesotho. The Electoral Institute of Southern Africa (EISA), Occasional Paper, No. 15, December.

Przeworski A (1991) Democracy and the Market: Political and Economic Reforms in Eastern Europe and Latin America. New York: Cambridge University Press.

Ramadubu D (2014) AU Facilitates Lesotho Generals' Exile. Botswana Guardian, 1 December. Available at: http://www.botswanaguardian.co.bw/latest-news/1162-au-facilitates-lesothogenerals-exile.html.

Renegade Lesotho General Seizes Weapons (2014). Mail and Guardian, 6 September. Available at: http://mg.co.za/article/2014-09-06-renegade-lesotho-general-seizes-weapons.

Reynolds A, Reilly B and Ellis A (eds) (2005) Electoral System Design: The New International IDEA Handbook. Stockholm: International Institute for Democracy and Electoral Assistance. 
Rich T (2015) Duverger's Law in Mixed Legislative Systems: The Impact of National Electoral Rules on District Competition. European Journal of Political Research 54(1): 182-196.

Rich T, Banerjee V and Recker S (2014) Identifying the Institutional Effects of Mixed Systems in New Democracies: The Case of Lesotho. Journal of Asian and African Studies 49(6): 637-653.

South Africa (2014) Communiqué by SADC Facilitator Deputy President Cyril Ramaphosa: Maseru Facilitation Declaration. 2 October. Available at: http://www.thepresidency.gov.za/pebble.asp?relid=18118

Southern African Development Community (2015) SADC Electoral Observation Mission (SEOM) to the Kingdom of Lesotho. March 2. Available at: http://www.sadc.int/files/4814/2536/7810/SEOM_STATEMENT_LESOTHO_final__02.03.2015.pdf

Tefo T (2014a) Metsing Angry Over Corruption Charges. Sunday Express, 4 August. Available at: http://sundayexpress.co.ls/metsing-angry-over-corruption-charges/.

Tefo T (2014b) Metsing's Corruption Trial Set for 9 September. Lesotho Times, 1 September. Available at: http://lestimes.com/metsings-corruption-trial-set-9-september/>.

United Nations, Secretary General Ban KM (2015), Statement Attributable to the Spokesman for the Secretary-General on the Parliamentary Elections in Lesotho. March 1. Available at: http://www.un.org/sg/statements/index.asp?nid=8426

Wanjiru E (2015) Tension is High as Lesotho goes to the polls. Deutsche Welle, 26 February. Available at: http://www.dw.de/tension-is-high-as-lesotho-goes-to-the-polls/a-18282748.

Zuma to Meet Thabane in South Africa as Lesotho Calms (2014). Deutsche Welle, 1 September. Available at: http://www.dw.de/zuma-to-meet-thabane-in-south-africa-as-lesotho-calms/a17892681. 